\title{
The Polemics of Conflicting Modernities
}

The conventional character of Ramalinga's 1867 publication did not mean that it was uncontroversial. Indeed, Ramalinga's claim that he belonged in the lineage of revered Shaiva poet-saints, and that his poems constituted a new addition to Shaiva canon, were antithetical to new considerations of religious authority that were coming to define reform Hinduism. Cosmopolitan leaders viewed canon as closed and complete, and they rejected new bids for inclusion. Ramalinga's claim that his poems announced a new revelation challenged this view and led to an acrimonious dispute over Shaiva canon and authority. A close analysis of this conflict gives us insight not only into Tamil Shaiva debates but also into contrasting styles of religious leadership and practice that characterized transformations of religion in colonial India.

The tensions between Ramalinga's vision of Shaivism and that of emerging reform positions, which were allied with established Shaiva institutions, came to a head in the years following the publication of Tiruvarutpā. In 1869, the Tamil Shaiva leader Arumuga Navalar published a critical response to Ramalinga's volume. A heated dispute followed that lasted for decades. In his polemic, Navalar punned that Ramalinga's verses were "marutpā," verses that confused and deluded, not "arutpā," verses of divine grace. Their conflict was not just one between two very prominent, and very different, Shaiva leaders. It also highlights the chasm between two influential and contrasting visions of Tamil Shaivism that were characteristic of broader redefinitions of religious tradition and authority in South Asia. This dispute gives a fascinating glimpse into the tensions between, on the one hand, new criteria of authority developed in colonial contexts and, on the other, notions of authority that were more closely grounded in precolonial traditions. 
While scholarly work on Ramalinga has been fairly thin, there have been many excellent studies of Navalar in the past three decades, in both English and Tamil. ${ }^{1}$ As with Hindu reform leaders more generally, the scholarly interest in Navalar results from his engagement with Western discourses and agendas. He was a cosmopolitan figure who learned from, and then opposed, missionaries, and he drew on Western ideas and models in his efforts to reframe Shaivism. It is Navalar, therefore, who has been called "the father of the Tamil renaissance" 2 and "the leading activist in Saivism . . . until his death in 1879." ${ }^{3}$ R. Balachandran asserts that "Navalar was responsible for the modernization of Saivism in Tamilnadu." ${ }^{4}$ argue here that Ramalinga has as much a claim to these titles and achievements as Navalar. Indeed, Ramalinga would inspire perhaps the greatest intellectual leader in Tamil Shaivism in the twentieth century, Maraimalai Adigal. ${ }^{5}$ Ramalinga came to serve as an influential figure for Tamil nationalists in the twentieth century. He is well known among Indian Tamils today, his popularity cutting across caste and class, while Navalar is little known except among scholars. Even if Ramalinga was on the margins of colonial cosmopolitanism, he was not marginal to the thousands of Tamils who followed him in his lifetime and after, nor should he be simply a footnote in studies of the emergence of modern Hinduism. My goal in this chapter is to consider together the two contrasting visions of Shaivism advocated by Ramalinga and Navalar, in order to clarify the crucial differences between them. The fact that both figures played pivotal roles in the transformations of Tamil Shaivism from their time to today suggests that genealogies of the emergence of modern Hinduism need to take greater account of both of their projects, as well as the innovations of other Hindu leaders working on the margins of colonial cosmopolitanism.

\section{REVISING TRADITION IN COLONIAL INDIA}

As we have seen in prior chapters, Ramalinga developed his vision of Shaivism through creative engagement with Shaiva devotional and siddha traditions. This contrasts with cosmopolitan reformers who drew on Western models and ideas in developing new notions of Hindu tradition. David Washbrook notes that "Indian 'tradition' had been re-defined and structured into society under colonial rule, apparently to a far greater extent than 'modernity' ever had been."' While economic relationships, social status, property, and other forms of power were marked by competition and fluidity in precolonial India, the colonial state sought to stabilize or "fix" these variables through new regimes of taxation, property ownership, law, and polities. Legal authority shifted from one of "dynamic and contestatory processes ... to the static principles of ancient precedent, hereditary succession and caste hierarchy." 7

The bases of authority themselves shifted in colonial contexts, where written sources took precedence over oral ones. According to Washbrook, local elites, 
especially brahmans, sought to redefine tradition in ways that served their economic and social interests. They adhered to a new "rhetoric of right" that conferred authority on the basis of antiquity and textual documentation. This redefinition was characterized by stricter conformity to brahmanical norms, greater social stratification, greater authority of texts, and a notion that tradition is permanent and unchanging. What emerged was a "neo-colonial constructed 'tradition' of . . . Anglo-Brahminised 'Hinduism,'” within which claims for tradition were framed as existing in a static state from "time immemorial." ${ }^{8}$ Likewise, elements of past tradition that did not conform to these criteria were increasingly marginal to central considerations of power. Washbrook reads these efforts as acts of resistance, in which Indian elites made claims to social and economic power, often at the expense of the colonial state. Of course, at the same time these were also acts of oppression, in which elite Indians consolidated their wealth and status at the expense of those who did not enjoy the privilege of a textual corpus stacked in the favor of upper castes.

The process of this redefinition of tradition was diffuse and entailed a variety of sites of contestation. Lata Mani has shown how debates about sati in the early decades of the nineteenth century occupied a range of actors, including reformers, conservative Hindus, and colonial administrators. ${ }^{9}$ Despite their varied positions, they largely agreed that any argument in favor of, or opposed to, the banning of sati needed to be made on the basis of scriptural evidence. In cosmopolitan settings, these debates enhanced the status of brahmanical texts at the expense of everyday, customary practices. Rammohan Roy argued that "original" texts should guide the debate on sati, as ancient scripture could serve as "the only safe rule to guard against endless corruptions, absurdities, and human caprices."10 For Roy, Dayananda Saraswati, and other cosmopolitan reformers, Hindu traditions had been compromised by centuries of revision and interpolation, and so they advocated textual fundamentalism in seeking an authentic, unified Hindu tradition. ${ }^{11}$ Mani notes that this emphasis on textual authority was not, however, a return to earlier notions of tradition but was "a modern discourse on tradition . . . one in which both 'tradition' and 'modernity' as we know them are contemporaneously produced." ${ }^{12}$ As Robert Yelle notes, it was also a Protestant discourse, one that took shape in the Reformation in opposition to Catholic ritual and idolatry.13

Law played a particularly important role in the emergence of these new notions of tradition. These legal contexts highlight the role of the colonial state in reconfigurations of Hindu tradition, usually in line with brahmanical ideals. Rosane Rocher notes that the bias toward textual authority was inscribed in Anglo-Hindu law at its conception. This judgment of canon as the sole authority was consistent with Protestant conceptions of sola scriptura, and it also reflected European views that Indian civilization had decayed from a prior golden age. ${ }^{14}$ Davis and Lubin note that another of the effects of the imposition of colonial law was the redefinition of Hinduism as a unified tradition. "Aided by Indian social reform 
movements, colonial law helped to create a homogenous, unitary conception of Hinduism within which internal differences were hard to recognize."15 Practices that did not conform to high-caste ideals, such as hook-swinging rituals in South India, were consigned to the realm of custom, rather than religion, with its lower level of legal authority. ${ }^{16}$ This imperative to articulate a unified Hinduism can be traced to the beginnings of Anglo-Hindu law, which strove for "consistency" and "uniformity."17

These new notions of tradition took hold in cosmopolitan contexts. In the courts, the colonial state determined the criteria by which claims could be legitimated. Nicholas Dirks notes that European administrators and Orientalist scholars sought to build an archive of knowledge about Indian castes and customs, which also contributed to these processes of traditionalization. "Regulation and knowledge thus collaborated in the fixing of tradition, by which I mean both the stabilizing and the repairing of a canonic sense of what had always been done." ${ }^{18}$ Christian leaders also played a vital role in this process, formulating a unified Hinduism based in brahmanical texts. ${ }^{19}$ Indigenous actors were crucial in advancing these processes. Indian litigants exploited the biases of Anglo-Hindu law to secure property claims. ${ }^{20}$ Pandits played a crucial role in providing evidence for courts, and they also were vital to the development of Orientalist knowledge. ${ }^{21}$ Donald Davis and Timothy Lubin suggest "that modern Hinduism emerged through the force of government legal power and educated Hindu opinion operating in tandem to 'reform' Hindu institutions and practices." 22 They are certainly right to point to the Indian engagement with European institutions and ideals as central to this cosmopolitan redefinition of tradition, even if we can question their equation of this process with the emergence of modern Hinduism.

Mani highlights that one of the most important effects of this cosmpolitanization of tradition was to marginalize certain forms of authority, including orality and customary practices. However, outside cosmopolitan contexts, one might expect that these new formulations of tradition faced stronger contestation by views drawn from premodern conceptions or by novel expressions. Indeed, Ramalinga and Navalar disagreed not only about the content of tradition, but also about the very form tradition should take and its bases of authority. Navalar largely adhered to emerging cosmopolitan views that were coming to dominate reform Hinduism throughout India. Ramalinga, on the other hand, drew from prior Shaiva conceptions in describing tradition as flexible and living. His emphasis on orality over written text, presumption to make a new contribution to the Shaiva canon, and announcement of a new revelation all ran counter to new definitions of tradition as textual, static, and brahmanical.

Print served to advance both of these contrasting positions. Navalar and other reform leaders used print to expand the accessibility and influence of canonical works, while, as we have seen, Ramalinga used print to stake a claim for the canonical status of his own writings. Thus, it is difficult to argue that print better served 
established power or marginal voices. What is indisputable, though, is that print facilitated conflict between contrasting positions. It was, after all, the printing of the 1867 volume that sparked the conflict between Ramalinga and Navalar. The role of print in exacerbating conflict was not limited to colonial South Asia but was also apparent in early modern Christendom. As Elizabeth Eisenstein writes, "Heralded on all sides as a 'peaceful art,' Gutenberg's invention probably contributed more to destroying Christian concord and inflaming religious warfare than any of the so-called arts of war ever did." ${ }^{23}$

In nineteenth-century India, print facilitated the participation of new constituencies in public debate, and the capacity of print technology to propagate messages quickly and relatively cheaply made it an ideal medium for polemical exchange. It was in part due to print that critique was one of the primary modes of religious expression at the time, with religious leaders and groups engaging in often virulent debates and even litigation. ${ }^{24}$ In Tamil, the acrimonious exchange between the parties of Ramalinga and Navalar was just one instance of wider polemics, as rapid religious, social, and technological changes led to hostilities over ritual, authority, and community. A.R. Venkatachalapathy notes that Tamil kanțanam or polemical literature records debates between Hindus and Christian missionaries, and also between Hindu sects, primarily Vaishnava and Shaiva, with Navalar being the most prolific contributor. ${ }^{25}$ This literature provides rich material for analysis, documenting important conflicts about community, authority, ritual, canon, and caste.

The chasm between the Ramalinga and Navalar factions encapsulates many of the tensions between two important contrasting formulations of traditions, marking a crucial divide in South Indian Hinduism over the terms of Shaiva community, leadership, and authority. After outlining some of Navalar's broader projects, I will look closely at his critique of Ramalinga's verses in order to highlight how his vision of Shaivism differed in fundamental ways from that of Ramalinga. Then, I will turn to a written response published by one of Ramalinga's followers. Their polemics illustrate the contrast between new forms of authority in colonial India and other, non-elite, less cosmopolitan considerations of religious power. As we will see, their positions are not easily described according to templates of reform versus orthodox, or modern versus traditional. My analysis demonstrates that tradition, like modernity, is a contested category that is ever-changing, and that both Ramalinga and Navalar articulated visions of Shaivism that were relevant to their world. More broadly, then, I question the equation of cosmopolitan reform Hinduism with modern Hinduism.

\section{NAVALAR'S COSMOPOLITAN FORMULATION OF SHAIVA TRADITION}

Arumuga Navalar (1822-1879) was born as Arumugam Pillai in Jaffna, Sri Lanka, an important center of Tamil Shaivism that also had an influential missionary 
presence in the nineteenth century. He was born into a Karkatta vellalar family, a dominant landowning caste. He had a traditional Tamil education, and at the age of thirteen he was sent to the Wesleyan Mission School in Jaffna for English schooling. He eventually worked with the missionary Peter Percival in Jaffna, helping to translate the Bible into Tamil. ${ }^{26} \mathrm{He}$ drew on these linguistic and cultural worlds-Tamil, English, Shaiva, and Christian-in developing his style of Shaiva revivalism and transforming Tamil modes of communication. Navalar's educational and professional history was thus thoroughly cosmopolitan, similar to reform figures in other regions of India. His recasting of Shaiva tradition shared much with the emerging cosmopolitan views of tradition discussed above. That is, he sought to reformulate a Shaiva tradition that was centered on texts, highly systematized, and elite in its authority and practices.

Through his translation work in the mission, Navalar came to regard texts as paramount in shaping a new and enduring religious community that could resist the proselytizing efforts of Christian missionaries. He asserted that divine grace could only be found in a closed corpus of texts, a view that led him to protest Ramalinga's claim of a new revelation. For Navalar, the touchstone for authority was always the past, not the present, and he rejected contemporary Hindu practices that did not have scriptural precedence. He worked to systematize Shaiva theology and ritual on the basis of canonical texts, most importantly, the Sanskrit Agamas and works of the Tamil Shaiva Tirumurai. Navalar's goal to establish a unified Shaivism was perhaps best exemplified in his campaign to standardize temple rituals, which often brought him into conflict with temple priests. ${ }^{27}$ This was an elite project, since Navalar gave particular importance to the liturgical prescriptions of the Agamas, works that emphasize ritual hierarchies based on caste. His formulation required scholarly and priestly leaders to perform rituals and communicate ethics, theologies, and practices to a community of Shaivas. He received significant support from the powerful Tiruvavadudurai monastery in Tamil Nadu, which provided economic patronage and an institutional home, and which conferred on him the title of "Navalar," "he of the mighty tongue." Navalar's Shaivism was based on caste, scripture, hierarchy, and powerful institutions.

Although Navalar's message was elite, he sought to reach a broad audience of educated Shaivas, employing print to spread his hierarchical vision of Shaiva community and authority ${ }^{28} \mathrm{He}$ engaged in multifaceted scholarly and publishing enterprises, writing prose renditions of canonical works, editing and printing classical Shaiva texts, developing school readers, and writing polemical literature. He focused his attacks on Protestant missionaries, but he was also critical of Shaiva institutions and leaders who did not conform to his view of Shaivism. ${ }^{29}$ In his eager employment of print, Navalar was likely influenced by his work with Percival on a Tamil Bible translation and publication, and also by anti-missionary Hindu societies in Madras. These Hindu societies effectively used print to propagate their messages after the press in India was deregulated in 1835, allowing Indians to run their 
own presses..$^{30}$ On a trip to India in July 1849 , Navalar bought a printing press in Chennai and brought it back to Jaffna, setting up the "Preservation of Knowledge Press." ${ }^{31} \mathrm{He}$ installed the press at his "School of Shaiva Splendor," which would challenge the missionary schools that dominated Jaffna education at the time. ${ }^{32}$

Among the earliest publications of Navalar's press was his 1852 prose rendition of the Tamil Shaiva classic Periya Purānam. ${ }^{33}$ He intended that the work be broadly read among Shaivas, writing on the title page that "This book has been rendered in prose form by Nallur Arumuga Navalar, so it is readily accessible to all Shaivas, learned and otherwise." ${ }^{34}$ Despite this goal to reach a broad audience, he was not advocating a sort of solus Christus or rejection of sacerdotalism. Rather, he insisted that all Shaivas should seek out an experienced preceptor and undergo initiation. ${ }^{35}$ Navalar chose the Periya Purānam for his prose rendition because it upholds hierarchical principles while extending Shaiva community to a range of caste communities. ${ }^{36} \mathrm{He}$ considered it to be one of five works essential for Shaivas to understand, along with the Tèvāram, Tiruvācakam, Tiruvicaippāa, and Tiruppallāntu. These five works constitute the bulk of the Shaiva devotional canon, the Tirumurai. Navalar calls these works "aruṭā," verses of divine grace, the term that Toluvur Velayuda Mudaliyar would later give to Ramalinga's verses. Navalar notes that these works are called "arutpā" because they were composed with the grace of Shiva, and because they could be used liturgically, recited in a variety of temple rituals. ${ }^{37}$ For Navalar, the designation of a work as "Tiruvarutpā" stakes a claim for that work's canonical and ritual status.

Navalar's emphasis on textual authority, and his publishing efforts that made canonical works more widely accessible, shares much with the projects of other cosmopolitan reformers. As we have seen, Rammohan Roy and Dayananda Saraswati similarly redefined Hindu traditions on Vedic works, and they published commentaries and translations of these works in order to render canonical work in accessible language. These reformers took liberties in their translations and renditions. Dermot Killingley notes that Rammohan Roy claimed to follow Shankara's Vedantic reading of the texts, but he often diverged in his translations and interpretations from his claimed sources..$^{38}$ Navalar's rendition of the Periya Purānam was not always faithful to Cekkilar's original, as he made important deviations from the text to suit his agenda. ${ }^{39}$ For these figures, past texts provided content for their contemporary reformulations of Hindu traditions, and they were also symbols of authority that reformers filled with new meanings and messages.

While much in Navalar's view of Shaiva tradition corresponds to broader cosmopolitan models of tradition, he also departed from these pan-Indian sensibilities in significant ways. By stressing the authority of the Sanskrit Agamas but also Tamil canonical traditions, his elitism was one that conferred power on high-caste, non-brahman, vellalar traditions like his own, as well as on brahmanical traditions. He highlighted the importance of non-brahman ritual roles, such as the singing of the Têvāram verses in temple rituals, while upholding the 
primacy of Sanskrit in ritual practices. Moreover, he maintained close links with powerful non-brahman monasteries, which were influential in Shaiva scholarly traditions, and emphasized their institutional importance to Shaivism. As a nonbrahman Tamil scholar, he did not hesitate to criticize brahmans whose ritual practices did not adhere to the Agamas, bringing him into frequent conflict with temple priests. ${ }^{40}$ At the same time, he maintained a general commitment to the dictates of varnashrama, caste duties, by limiting authority to upper castes; maintaining that dalits should be excluded from temple worship; and advising that if dalits wish to undergo Shaiva initiation, they must seek out a preceptor specific to dalit communities. ${ }^{41}$

Navalar's insistence on the centrality of ritual practice also departed from other Hindu reform ideologies. He did not seek to rationalize Hinduism along the lines of a Vedantic view of philosophical monism. Gauri Viswanathan notes that many cosmopolitan Hindu leaders in the nineteenth century worked to distance themselves from Hindu iconographic traditions as a result of colonial and missionary critiques of Hindu "idolatry." These leaders turned to Vedanta as a rational, monotheistic Hindu philosophy, which displayed an intellectualism that was even superior to that of Christianity..$^{42}$ For Navalar, ritual continued to be central to Shaivism. He did, however, seek to transform temple ritual, attacking practices that might be characterized as "folk," such as the worship of minor deities or the performance of animal sacrifice. ${ }^{43}$

One further crucial departure from pan-Indian cosmopolitan sensibilities was his promotion of Tamil Shaivism rather than a broader Hindu community. He did seek to unify and systematize his tradition, but only Shaivism, and only among Tamils. This is, I think, in part due to his personal status as a vellalar whose claim to expertise was founded on his mastery of Tamil. The entirety of his publishing work focused on texts in Tamil, consistent with his education and upbringing in a vellalar family. Those Hindu leaders who formulated a unified Hinduism based their efforts on Sanskrit works that they claimed were the basis of all expressions of Hinduism. Navalar's knowledge of Vedic works appears to have been minimal, and it would have been difficult to formulate a broad, pan-South Asian Hindu community on the basis of Tamil texts. Furthermore, there are no important nonsectarian Hindu works in Tamil, so he was limited to a sectarian formulation. The audience he addressed, and the community he redefined, was a Tamil Shaiva one.

Navalar reformulated Shaiva tradition in a way that grounded its authority in Sanskrit and Tamil canonical works in an attempt to systematize its ritual practices and principles. He pursued this redefinition in a period of conflict and contestation. His new articulation of Shaiva community was born out of his opposition to Christian missionaries. This led to frequent polemics, and like some other cosmopolitan leaders, Navalar displayed throughout his life a love for controversy. He presented himself as a champion of native religion against the proselytizing efforts of foreign missionaries. Moreover, as a figure of the Shaiva establishment, he tried 
to marginalize and at times eliminate Shaiva texts and practices that he deemed to be contrary to textual orthodoxy. In particular, he attacked practices, ideologies, and claims to authority that did not adhere to Agamic strictures. ${ }^{44}$ In the late 1860s, he turned his attacks to Ramalinga, whose canonical claims and assertions of an accessible Shaivism challenged Navalar's vision of a hierarchical community subject to the authority of established texts and leaders.

\section{NAVALAR'S CRITIQUE OF RAMALINGA}

The debate between these two camps, one loyal to Navalar and the other to Ramalinga, began soon after the publication of Tiruvarutp $\bar{a}$ and continued into the 1980 s. $^{45}$ Ramalinga's followers made their case by assuming that Shaiva tradition was alive, flexible, and able to accommodate new revelations and scriptures. Navalar and his followers advanced a position that paralleled emerging cosmopolitan notions of tradition that I described above, namely, the closed character of canon, a bias toward textual authority, and the impossibility of a new revelation. They attacked Ramalinga's character and scholarly accomplishments, questioned his authority, and ridiculed the quality of his writings. Here I will discuss Navalar's critique, and in the next section I will detail the response of one of Ramalinga's followers.

The most important contribution to the conflict from the Navalar camp was by Navalar himself, a twenty-page pamphlet entitled "Pōliyaruṭpā Maruppu," or "Critique of the Pseudo-Divine Verses." Navalar published his critique in 1869 under the name Mavandur Tyagesa Mudaliyar. ${ }^{46}$ As Venkatachalapathy points out, it was not unusual for authors to publish polemical tracts under false names. ${ }^{47}$ There is common agreement that the author of the work was, in fact, Navalar. ${ }^{48}$ The tone and content clearly point to Navalar's authorship, and the tract itself ends with the summary of a letter in Navalar's possession. It appears that Navalar gave lectures attacking Ramalinga and Tiruvarutpa a teast a year before publishing his critique. One of Ramalinga's followers, Shanmugam Pillai, had already published a response to Navalar's criticisms in January-February 1868. In this response, which I will analyze later, Pillai gives a summary of a lecture by Navalar that includes many of the criticisms that Navalar would publish in $1869 .{ }^{49}$ Although Navalar's critique was published two years after Tiruvarutpa $\bar{a}$ 's publication, his public opposition to Ramalinga's work began at least a year earlier.

Navalar begins his critique with a list of five works that he describes as "aruṭpā." These are the Tévāram, Tiruvācakam, Tiruvicaippā, Tiruppallānțu, and the Periya Purānam, the same five that he named in his preface to Periya Purānam. Because they are regarded as "aruṭā," they are qualified to serve as liturgical texts for a variety of Shaiva rituals. Navalar cites the text Tirukkōvaiyār Unmai as the authority for this view..$^{\circ}$ This is a work that advances an allegorical interpretation of the devotional and often erotic verses of Tirukkōvaiyār. The Tirukkōvaiyār Unmai has 
been important to monastic scholars, with the Tiruvavadudurai monastery publishing C. Dandapani Tecikar's 1965 commentary on the work..$^{51}$ Navalar cites additional Shaiva doctrinal texts, both Tamil and Sanskrit, that testify that these five works present the words of Shiva, because the authors of these texts, the nāyanmār, transcended ordinary perception and achieved knowledge of Shiva. He notes that "texts mentioned in the Civarakaciyam" confirm that the words of the nāyanmār are $\operatorname{arutp} \bar{a}$, and that their poems display the most affection toward Shiva of any of the Vedas. He refers to "Tattuva Pirakācam, etc." as texts that outline the proper worship of Shiva and the nāyanmār. He also asserts that the recitation of these five texts has been a part of temple ritual from ancient times. ${ }^{52}$ These five works cover much, but not all, of the Tirumurai, the Shaiva devotional canon. His list omits Tirukkōvaiyār itself, Tirumantiram, and the various works of the eleventh section of the Tirumurai. In highlighting that only certain works of the Shaiva canon are deserving of the name "aruṭpā" Navalar asserts a view that departs from more inclusive canonical understandings of Tamil Shaiva tradition.

According to Navalar, canonical status must be adjudicated on the basis of doctrinal authority and ancient usage, not on present-day assessment of the literary or soteriological qualities of a text. The claim of any work to be arutpa $\bar{a}$ therefore requires the authorization of past tradition. For Navalar, this tradition consists of learned works that wield authority in Shaiva scholastic traditions. In citing doctrinal evidence for his position, Navalar suggests that the category of arutpa $\bar{a}$ is closed and that only these five works qualify. For Navalar, Shaiva authority is scriptural, established in monasteries, and realized in long-standing practices that date to ancient times. His insistence on a limited canon of established texts was consistent with broader processes of cultural and religious debate in nineteenth-century South Asia.

Navalar then turns his attention to Ramalinga, presenting a contrast between this hallowed, ancient, scholarly Shaiva tradition, and Ramalinga's verses. "Currently someone named Ramalinga Pillai of Karunguli has composed a few poems so that the general population ('ulakattār,' or 'people of the world') will worship him, believing that he has realized Shiva. He calls himself 'the generous one with the splendor of holy grace', and he calls his verses Tiruvarutpā. He has had one of his students compose a mythological account (purānam) about him called 'Tiruvarutpā Varalāru,' which he added to the end of the work, published it, and is selling it." ${ }^{33}$ Navalar worries that Ramalinga's influence threatens the recitation of the five established arutpa $\bar{a}$ works in temples. "A few ignorant people consider Ramalinga Pillai equal to the Shaiva saints, and consider his verses equal to the Tévāram and Tiruvācakam. They recite his verses when performing puja [worship rituals] and Shiva darshan [viewing the deity]. A few times in Chennai, at a few temple festivals, they have stopped reciting Têvāram, etc., and instead recite Ramalinga Pillai's verses." ${ }^{54} \mathrm{He}$ portrays Ramalinga as a demagogue with followers who are complicit in perpetuating a perception of Ramalinga's divinity. 
Navalar was right to suggest that Ramalinga presented himself as a Shaiva saint, as I have shown earlier. Navalar also stresses that Ramalinga and his followers are "selling" his work, implying that they seek to enrich themselves. Most troubling for Navalar, though, was the singing of Ramalinga's verses in Shaiva temples. The ritual recitation of Ramalinga's verses appears to have been widespread. A few years later, in 1875, in his long-standing dispute with temple priests and managers of the Kandasami temple in Jaffna, Navalar notes that even in northern Sri Lanka priests were using Ramalinga's verses. ${ }^{55}$ This ritual use of new verses by someone claiming to be a saint, at the expense of established works authorized by long-standing traditions of exposition and legend, presented a clear challenge to Navalar's notion of canonical authority based in revered scripture, established doctrine, and ancient usage.

Navalar's response testifies to the growing popularity of Ramalinga's teachings and writings. It also highlights the emerging power of print. While Ramalinga's verses were being sung at temples even before 1867 , the publication of Tiruvarutpa had the potential to further extend their influence. This is why it was the publication of the work that compelled Navalar's response. Navalar worried about Ramalinga's influence on the "ulakattār," the "people of the world." It is this broader Shaiva public that Navalar addressed in his own publications, so Ramalinga's book posed a direct challenge to Navalar's efforts. Navalar's primary concern was the ritual use of Ramalinga's verses, not that Shaivas would read them in quiet reflection. In Shaivism at this time, it appears that print did not replace orality but facilitated it through spreading content for ritual recitation..$^{56}$ With the publication of Tiruvarutpā, print helped to expand the content of Shaiva ritual. This was directly opposed to Navalar's publication project, which sought to systematize Shaiva ritual by limiting its basis to specific scriptures. These two important Shaiva leaders used print for contesting ends, highlighting the power of print to serve positions of established authority as well as critiques of that power.

Perhaps the greatest challenge that Ramalinga posed to Navalar was the potential to win over Shaivas to his vision. Navalar declares his concern for Shaivas, addressing his tract to "people of the world." He calls those who have begun to follow Ramalinga, and who have begun to sing his verses in temples, "ignorant," "simple people," and "fools." "These simple people have become confused and corrupted because Ramalinga and his students go around saying that he knows alchemy and performs lots of miracles, and his poems state that he has received divine grace." Navalar states that he has written this polemical tract to expose Ramalinga's deception of "those simple people" out of "sympathy" for them. ${ }^{57}$ Navalar's concern for those who have chosen to follow Ramalinga suggests some overlap in the audiences that these two Shaiva leaders sought to address. Indeed, Navalar hoped that his publications would reach both literate and illiterate audiences, suggesting in the preface to his prose Periya Purānam that literate Shaivas read the work aloud to illiterate listeners. ${ }^{58}$ Devadarshan Ambalavanar notes that Navalar addressed 
a collective audience of Shaivas, often using the term "canankal," "people," rather than specific groups such as priests, teachers, or scholars. However, this Shaiva public did not extend to dalit castes, nor perhaps even to low-caste shudras. ${ }^{59}$ Dagmar Hellmann-Rajanayagam points out that Navalar's primary audience consisted of "satsudras," that is, upper-caste vellalars like himself. ${ }^{60}$ Ramalinga's audience would likely have been broader than Navalar's, including lower-caste Shaivas who would have been attracted by Ramalinga's stress on accessibility and rejection of elite ritual practices. This may explain why Navalar took such a patronizing attitude toward those people who were attracted to Ramalinga because of his miracleworking fame.

Navalar proceeds by presenting specific verses from Tiruvarutpā, focusing on passages in which Ramalinga claims that he performed extraordinary acts or had direct experience of Shiva. Navalar cites a verse in which Ramalinga declares that Shiva "entered inside of me, spoke secretly, and made me understand everything without formal study." ${ }^{11} \mathrm{He}$ points out that Ramalinga's education is in fact well known, and he questions the extent of Ramalinga's knowledge. "When saying that 'I knew everything without formal study', does that mean all languages? Or only two, Sanskrit and Tamil? Or only one, Tamil? Is that all texts in Tamil? Is it all texts in the fields of grammar, literature, and philosophy? If that's the case, what is the explanation for all the errors in his published books?"62 Navalar ridicules Ramalinga by literally reading Ramalinga's vague claim that Shiva helped him to realize "everything." ${ }_{33}$ Most importantly for Navalar, Ramalinga lacks the formal training of the sort modeled at Shaiva monasteries. This critique of Ramalinga's scholastic credentials is one that Navalar repeats several times in his tract.

Although Tiruvarutpa is not a scholarly text, Ramalinga did produce two works in which he engaged in scholastic activities. These were a commentary published in 1851 on the doctrinal work Olivil Otukkam and a contribution to a debate about the proper use of the term for the northern Tamil region, “Tontaimantalam," published as Tontamantala Catakam in 1855. Navalar ridicules Ramalinga's claim to have "realized everything" by pointing to his scholarly failings in the $1851 \mathrm{com}$ mentary on Olivil Otukkam. He criticizes Ramalinga's ignorance of a "basic doctrine that any educated person would know," noting that Ramalinga mistakenly includes Brahma, et cetera, in the intermediate class of beings. He lists grammatical mistakes that he found in the work and jokes that finding errors in Ramalinga's commentary is as easy as finding grains of sand on a beach. He contrasts Ramalinga to the seventeenth-century Shaiva poet Kumarakuruparar, who was dumb until he received the grace of Murugan when he was five years old. Despite lacking formal education, Kumarakuruparar composed a poem in praise of Murugan which was free of grammatical errors, and which contained the truths of Shaiva Siddhanta teachings. He is a celebrated figure in Shaiva literary and monastic history, taking initiation at the Dharmapuram monastery and later establishing his own monastery in Benaras. ${ }^{64}$ Navalar expresses amazement that Ramalinga, who "lacks the 
learning of a child," has claimed a similar status. ${ }^{65}$ For Navalar, grammatical accuracy was not just a scholarly virtue or an exclusively secular concern, but it was also a sign of sanctity and a prerequisite of sainthood. He asserted that scholarly learning was best exemplified in monastic institutions, making institutional affiliation essential to claims of revelation. Ramalinga was therefore doubly removed from Navalar's criteria for sainthood, producing defective poetry independently of the auspices of established Shaiva institutions.

Turning from his critique of Ramalinga's scholarly credentials, Navalar questions Ramalinga's reputation as a thaumaturge, ridiculing his claim to have lit a lamp using water as fuel. He cites a verse of Ramalinga's from Tiruvarutpā: "Oh friends of famed Chennai, listen to what I say! I lit a lamp with water, as if it were oil, in front of god." ${ }^{66}$ Navalar then cites two other verses recounting this event, one from Velayuda Mudaliyar's Tiruvaruṭpa Varalāru, and the other Chidambara Swami's prefatory verse to Tiruvarutpā. He questions whether these two supporters saw Ramalinga light the lamp with water, or if they just heard him say that he did. Navalar focuses on the prefatory verse, which praises the power of Ramalinga's path by citing "the event when water had power to fuel a lamp's flame." The verse is attributed to "Chidambara Swamigal, of the Madurai Tirugnanasambanda Swamigal Monastery, the renowned seat of religious teachers of pure Shaiva Siddhanta based on the Vedas and Agamas." ${ }^{67}$ This is one of the only references in Tiruvarutpā that links the work to monastic authority. Navalar seeks to question this connection, asking with some derision, which monastery does Chidambara Swami head? Navalar raises the possibility that Chidambara Swami did not actually write the verse himself, implying that it was Ramalinga or his followers who wrote it. ${ }^{68}$ Navalar is clearly eager to cast doubt on that monastic connection, asking "people of the world" to examine these things.

Navalar then challenges Ramalinga to demonstrate the truth of Shaivism by repeating this miracle in front of a large crowd of people, both Shaiva and nonShaiva, rather than "advertising it to friends in Chennai in verse." He contrasts Ramalinga with Naminandi Adigal, who used water to fuel lamps in a Shiva temple at Tiruvarur, to the consternation of Jains who had refused to provide him with ghee as fuel. ${ }^{69}$ According to Navalar, for Ramalinga to verify his claim that his verses are $a r u t p \bar{a}$, he would need to do no less than perform a public miracle..$^{\circ}$ Here, Navalar seeks to weaken Ramalinga's claims by casting doubt on his miracles, recognizing that stories of Ramalinga's extraordinary capabilities were contributing to his emerging authority and reputation as a Shaiva saint. He does not deny outright the possibility of the performance of miracles, stating quite clearly that Naminandi Adigal did indeed perform a miracle in public. Thus, we should not see Navalar's polemic as an attempt to thoroughly rationalize or disenchant Shaiva tradition. However, he restricts evidence for these miracles to the canonical past, dismissing the possibility of new revelations. Here Navalar clearly subscribes to a Protestant notion of revelation, as described by Yelle: "Many Protestants 
insisted further that, with the Passion, all miracles, magic, and mystery ceased, and the obscurely figurative language of both the pagan oracles and Jewish rituals was replaced by the illuminated 'plain speech' of the Gospel." ${ }^{71}$ Ramalinga's verses announced the occurrence of miracles and the accessibility of Shiva in the present, presenting a challenge to a Protestant model of tradition that was increasingly coming to define elite, cosmopolitan expressions of Hinduism.

Ramalinga's claim that he frequently had direct interactions with Shiva was essential for his bid for authority, because he remained outside established Shaiva institutional power. Navalar thus seeks to undermine Ramalinga's accounts of his personal interactions with Shiva. He ask his readers to consider the following verse from the Tiruvarutpā: "My master and guru dances in the radiant hall, destroying darkness. My lord revealed his form which is divine grace, his beautiful smile on his bright face, and distinctly touched me with his precious hands. He opened his jewel-like mouth, came close, spoke, and entered inside me. This is something new!"72 Navalar estimates that there are about two hundred verses in Tiruvarutpa in which Ramalinga claims direct experience of Shiva. Navalar asserts that these verses glorify Ramalinga, not Shiva. He points out that the benedictory verse by Ramalinga's "nephew" Ponneri Sundaram Pillai suggests that Ramalinga is an incarnation of Shiva himself. He challenges Ramalinga to glorify Shiva by performing miracles in public and by attacking other religious traditions. He contends that instead of these public displays, Ramalinga and his followers "hide" Shiva and announce that Ramalinga himself has risen up, bestowing grace. ${ }^{73}$ Although Navalar does not mention precisely which "other religions" Ramalinga should attack, given Navalar's own activities, it is likely that he has in mind Ramalinga's silence about Christianity.

Navalar next recounts an episode in which a brahman priest at the prestigious Chidambaram Nataraja temple took on Ramalinga as his guru. The priest was suffering from some sort of illness, and he appealed to Ramalinga for help. According to Navalar's account, Ramalinga promised to heal him but abandoned him instead, and the priest eventually died. Navalar notes that "even after he had died, Ramalinga told the world in Tiruvarutpā that he had cured the man, didn't he?" He continues, “This priest, born of a lineage of such high caste, character, and education that they refuse to bow down even to the exalted Shankaracharya Swamis, he fell at Ramalinga's feet, taking him as his teacher, and Ramalinga did not cure him." ${ }^{74}$ Navalar finishes his account implying that it was inappropriate, and ultimately foolish, for someone of such high caste to become a devotee of Ramalinga.

Navalar's critique is consistent with his support of caste hierarchies. He fears that Ramalinga's teachings and community of followers blur these caste practices, noting that Ramalinga had won the support of a few priests who had sided with Ramalinga and had rejected the recitation of the Têväram in temples. ${ }^{75}$ These critiques express caste tensions between Navalar and his followers, on the one hand, 
and Ramalinga and some of his closest acolytes, on the other. Navalar and the monastic leaders who supported him were high-caste vellalars, while Ramalinga's inner circle was composed of middle-caste groups who aspired to higher vellalar status. ${ }^{76}$ Venkatachalapathy points to these caste tensions, noting that the Navalar camp referred to Ramalinga as "Ramalinga the accountant," a reference to his middle-caste background. ${ }^{77}$ Ramalinga's accommodating formulation of Shaivism minimized the importance of caste, and in the case of his almshouse, and his verses published after his death, he was highly critical of caste. Ramalinga's vision for Shaivism was caste inclusive, and Navalar feared that Ramalinga would attract not only the poor and "ignorant" masses, but also upper-caste Shaivas, even those at the center of Tamil Shaivism, the Chidambaram Nataraja temple. His popularity, then, posed challenges to Tamil Shaiva caste structures, supporting claims to authority advanced by middle-caste groups.

It is unclear where Navalar learned the details of the Chidambaram priest episode. He mentions a number of other incidents that cannot be traced to the 1867 text, indicating that Ramalinga's legend went beyond that publication. These episodes provide interesting clues about Ramalinga's emerging hagiography. For example, Navalar reports that "for many years, Ramalinga's followers have entered every place, temple, home, and street, declaring that Ramalinga learned alchemy from Shiva himself; that he produced six large portions of gold through alchemy; that he would use that gold to build a town called 'Parvatipuram'; that he would build a golden hall there, which will spread the fame of Shiva, who will come to that very place and perform his dance; that they will feed all those who are hungry; that they will heal all the sick; and that they will teach all those who desire education." Navalar notes that the town is unfinished, and asks why they have not accomplished these things. He writes that Ramalinga made a promise to Chidambaram priests, in front of many people at the temple, in June-July 1866 , that he would use his gold made with alchemy to donate two hundred thousand rupees for their purification ceremony. Navalar notes that the payment has still not been made. He ridicules Ramalinga, asking why, if he knows alchemy, does he "roam from town to town, begging for money and rice?... Why were copies of his Tiruvarutpā produced through the subscriptions of others?"78

Some features of Navalar's description, such as alchemical knowledge and the power to heal the sick, highlight tantric and siddha influences that were largely absent in the 1867 publication, but which dominated later publications of Ramalinga's verses. Navalar goes on to mention two additional stories that Ramalinga's followers tell about Ramalinga, stories that bring out more clearly Ramalinga's legend as an accomplished siddha with extraordinary powers. In the first, two of his students had come from Chennai to have darshan of Ramalinga. After meeting, Ramalinga gave them a magical pill that allowed them to fly. According to Navalar's account, they claimed to have taken this pill and flew back to Chennai at twice the height of a coconut tree, arriving in less than an hour. 
In the next story, Ramalinga was speaking to a few officials in Chidambaram. Ramalinga suddenly moved a short distance away from them, explaining that his wife had just died in Chennai, rendering him impure. Three days later, news came from Chennai confirming the report. ${ }^{79}$ While Navalar goes on to ridicule these stories, they suggest that Ramalinga's popularity at this time was at least partly founded on hagiographical accounts of his extraordinary powers.

Navalar asks his readers to conclude that Ramalinga is a fraud. "The poverty of one who calls himself an alchemist; the disease of one who calls himself a doctor ... the poisoned, flawed knowledge of one who calls himself a wise man; don't all these reveal his words as lies?"80 Embedded in Navalar's critique, however, is confirmation of Ramalinga's influence among the "people of the world" and a grudging acknowledgment that he has won the patronage of wealthy benefactors. Some people considered his verses equal to the most revered Shaiva works, and they appear to have begun to neglect these established works. Navalar asks his readers to carefully consider the truth of his tract, urging them to take hold of "the true texts of the Têvarram, etc., recite them with faith and understanding according to custom, and attain salvation." ${ }^{\text {1 }}$ Navalar's concern, then, is not just with Ramalinga's students, but perhaps more importantly with his wealthy supporters, priestly following, and a general public that Navalar was himself courting. He hopes that these Shaivas will realize their folly and again respect established forms of ritual and authority.

Navalar ends his polemic with an episode that emphasizes the superiority of monastic scholasticism and the inferior learning of Ramalinga and his students. The incident was a confrontation between two of Ramalinga's followers, Velayuda Mudaliyar and Muthusami Mudaliyar, and a supporter of Navalar's position, Ramasami Pillai. Navalar describes Pillai as a disciple of the Tiruvavadudurai monastery, an expert in grammar, literature, and Shaiva Siddhanta texts, and a "trusty scholarly advisor" to the head of the Madurai Tirugnanasambanda Swamigal Monastery. Pillai sent Navalar a letter describing the dispute, and Navalar published it in his tract for the benefit of the "general public." According to Pillai's letter, the encounter began when Muttusami Mudaliyar arrived at the monastery in Madurai, worshiped at a small temple there, and announced that Velayuda Mudaliyar, Ramalinga's "first student" and a great scholar of grammar, literature, Vedanta, and Siddhanta, would arrive the next day for worship. He asked if there was a copy of Tiruvarutpa at the monastery. Informed that there was no copy, he offered to send one from Chennai, and he recited some poems from Tiruvarutpa. At this point Ramasami Pillai protested the visitor's provocations. Pillai notes in an aside that the prior year he had "chased away" a mendicant who came extolling Ramalinga's interactions with Shiva, his knowledge of alchemy, and his lighting a lamp fueled with water. Muttusami Mudaliyar tried to engage Pillai in debate about Navalar's objections to Tiruvarutpā, but Pillai refused to be baited, waiting to debate Velayuda Mudaliyar directly. 
When Velayuda Mudaliyar arrived at the temple two days later, Ramasami Pillai greeted him before testing his knowledge of Shaiva Siddhanta doctrine. According to Pillai, Velayuda Mudaliyar was only able to respond to his questions with a basic level of detail that demonstrated little understanding. Pillai then moved onto the issue of arutpa $\bar{a}$, noting that of the twelve sections of Tirumurai, the tenth, the Tirumantiram, and the eleventh, a compilation of works, do not have the proper form or high quality to qualify them as arutpa $\bar{a}$. The remainder of the works of the Tirumurai are arutpa $\bar{a}$ and as such are sung in temples and at festivals. Pillai continues, "Ramalinga, wearing sacred ash and rudraksha beads, has given his verses the name 'Tiruvarutpa $\bar{a}$ ' and divided them into murai. Is this proper?" Velayuda Mudaliyar and Muthusami Mudaliyar responded that the five canonical works were not called "Tiruvaruṭpā" in Chennai, claiming regional differences in naming these works. Pillai ridicules them for this view, suggests that they inquire about this matter at monasteries, which will confirm their error, and asks "what sort of Shaiva tradition do you follow?" Pillai then tells them that they must have gotten confused and changed the name of Ramalinga's poems from "street verses of confusion" to "verses of divine grace." At this point, Velayuda Mudaliyar and his companion declined to answer any further questions, got up, and left. ${ }^{83}$

Ramasami Pillai mocks Ramalinga by calling his verses "terumaruṭpā," "street verses of confusion," instead of "tiruvaruṭpā," "verses of divine grace." This clever play on words was to become emblematic of the position of Navalar's camp, and the debate became known as the "aruṭpā/maruṭpā" debate. ${ }^{84}$ Pillai's appellation suggests that Ramalinga composed his poems in ignorance or with malice, and led astray those who were moved by them. Even more revealing was his replacement of tiru, which means holy or auspicious, with teru, the street. By referring to Ramalinga's poems as "street verses," Pillai characterizes them as common, public, pedestrian, unlearned, simple, and easily accessible. He insists that Ramalinga's verses were not in the same class as the elite literature of Shaiva tradition, celebrated by monasteries and sung in temples. As such, he rejects that Ramalinga's poems were "aruṭpā," suitable for temple ritual and worthy of esteem by educated Shaivas.

It is not clear, though, that Ramalinga would have rejected the "street" character of his poems, even in this period when he presented himself as a conventional Shaiva saint. In the 1867 verses, he celebrated the most accessible features of Shaivism, and in the same year he announced his almshouse to the poor. For Ramalinga, bhakti was not an elite genre, but one through which he could reach a broad audience with a popular message of equality. In his later poems, published after his death, Ramalinga abandoned established conventions and explicitly declared that Shiva was to be found on the streets, far from the world of doctrinal debates of the sort that Ramasami Pillai thrust upon Velayuda Mudaliyar. "Oh people of the world, you wander aimlessly, valuing caste, dogma, sects, noisy doctrinal debates, the disputes over lineage. Your wandering is useless, it is destructive 
and ugly. Stand in the good path of justice. The dancer is the only lord. Shiva's play of grace and light is occurring on the street. I call out: the right time has come." ${ }^{5}$ For Ramalinga, the street was the new site of Shiva's activity, available to all "people of the world," regardless of caste or sect.

For those upholding monastic authority and privilege, however, the common qualities of the street were distinct from those of the divine. For Navalar and other monastic authorities, the presence of Shiva's grace was found in doctrinal and devotional literature and institutions that were best exemplified in monasteries, and, less adequately, in temples. Indeed, it was in the highly regulated private space of monasteries that Shaiva authority could be most tightly controlled. For Navalar, the semipublic nature of temples made them contested sites subject to influence from the "streets," as evidenced by his criticism of priests who followed Ramalinga and by his long-standing conflicts with Shaiva temples over the proper forms of ritual performance. For Navalar, Ramalinga, and others who were redefining Shaivism, these spatial distinctions demarcated distinct spheres of authority, possibility, corruption, and danger.

With his critique of Ramalinga, Navalar sought to reign in Ramalinga's emerging fame as a Shaiva saint who wielded extraordinary powers and composed poems worthy of the Shaiva canon. He worried that the printing of Tiruvarutpa would advance Ramalinga's claims of sainthood and accelerate the popularity of Ramalinga's poems and their ritual use. His worries were well founded: by 1899, Ramalinga's verses were being included in published compilations of the Tèvāram. ${ }^{86}$ By insisting that revelation be testified by scripture, Navalar counters Ramalinga's notion of tradition as alive, flexible, and subject to change. He depicts Ramalinga as unlearned, an outsider to established institutions, and incapable of matching the literary standards of the Shaiva canon. Navalar's drew on emerging cosmopolitan notions of tradition in formulating a Shaivism that grounded authority exclusively in texts, located revelation in an ancient past, and resisted contemporary claims of miracles or of new revelations.

\section{A NEW REVELATION: A RESPONSE FROM THE RAMALINGA CAMP}

Ramalinga never directly participated in the dispute, but his closest followers did. The first published contribution to the debate was Shanmugam Pillai's 1868 “Tiruvaruṭpā Tūṣaṇa Parikāram," "Antidote to the Slander of Tiruvaruṭpā," which I analyze in detail below. ${ }^{87}$ Velayuda Mudaliyar also wrote a lengthy response to Navalar's critiques in $1969 .{ }^{88}$ The content of their responses adhere closely to Ramalinga's views of canon, revelation, the possibility of miracles, and the living character of Shaiva tradition.

In early 1868, Shanmugam Pillai attended one of Navalar's lectures in Chennai. According to Pillai, the lecture was advertised as a discussion of Shaiva initiation 
practices, but it was instead a sustained attack on Ramalinga. Pillai wrote a response called "Antidote to the Slander of Tiruvarutpā," which was published in January/February $1868 .{ }^{89}$ In his response, Pillai summarizes Navalar's critical comments, which are almost identical to those in the tract that Navalar would publish the following year. According to Pillai's account, Navalar began his lecture by outlining the criteria for inclusion in the category of arutpā; he attacked Ramalinga for claiming to have performed miracles; he questioned Ramalinga's scholarly credentials; and he warned that Ramalinga was preying on "simple people."90 Pillai's account indicates that within a year of the publication of Tiruvarutpa $\bar{a}$, the dispute between the two camps was under way. It also confirms that Navalar was indeed the author of the "Critique of the Pseudo-Divine Verses," as that publication precisely reiterated the criticisms that he was expressing in public lectures.

Pillai begins his response by questioning whether Navalar's attack on Ramalinga reflects Agamic sensibilities and scholarly learning. He cites two verses from the Tirukkural: "Virtue is acting without malice, envy, anger, and slander," and "Strive to learn, and after attaining faultless learning, put it into practice." Pillai suggests that Navalar does not know the meaning of these verses. ${ }^{91}$ The Tirukkural is a popular work of ethics, consisting of concise verses that outline everyday behavior and wisdom. It is an accessible non-Shaiva text with no apparent sectarian loyalty. Pillai's quotation of this popular work signals a significant departure from the scholastic works that Navalar cites.

Pillai then questions Navalar's insistence that only five works qualify as arutpā. He asks where in the Periya Purānam Cekkilar says that the other four works can also have the name arutpā. He continues,

Perhaps the authors of those five works appeared in front of Navalar, telling him that their works can be called "arutp $\bar{a}$," but no other works have the appropriate qualities so are not qualified to be called "arutpā." Or did Shiva himself appear in front of Navalar to tell him this? Or did Navalar hear this directly from a voice from the heavens? Or did he receive Shiva's grace and become a knower of the past, present and future? Did he take on a human body that is endowed with the divine perfection of omniscience, and then declare that other than Têvāram, Tiruvācakam, etc., no other texts have the splendor to be called "arutpa"? I've never known temerity like Navalar's. ${ }^{92}$

Pillai questions Navalar's authority to limit arutpā to only five works. He discounts the authority of Shaiva scholarly and theological traditions, highlighting that the most authoritative sources of Shaiva authority are Shiva himself and the Shaiva poet-saints, and they never expressed Navalar's position. He asserts that any texts with the appropriate characteristics should qualify as arutpā. When Pillai points out that Navalar does not know the past, present, and future, he implies that it is indeed possible for works of arutpa to be composed in the present and the future, 
not only in the past. By refusing to limit aruța $\bar{a}$ to revered texts composed in the past, he rejects Navalar's position that arutpā is a closed category of texts.

Pillai describes the characteristics that would qualify a work to be arutpā. He rejects that a poet needs to embody faultless virtue. He cites a verse from Tiruvācakam, in which Manikkavacakar describes himself as a flawed human being whose focus on Shiva wavers:

Oh, my dead heart! There's none like you! You don't dance; you have no affection for the anklet of the dancer [i.e., Shiva's feet]; you don't sing, your body melting with devotion; you don't get excited [at the thought of Shiva]; you don't serve him; you don't place his flower-like feet on your head, and you don't even garland them. You don't search for him on every street. You are indifferent. Your actions confound me. ${ }^{93}$

Pillai also includes a verse of Tayumanavar, a revered eighteenth-century Shaiva poet: "When I reflect on things, my heart is frightened, and I can't sleep. Even if I escape this birth, what will happen in my next birth?" Pillai includes these verses from Shaiva poet-saints as evidence that in addition to all the joy expressed in their works, the Shaiva poet-saints also sang poems expressing their doubts, fears, and fickleness, in order that they might receive Shiva's grace. Pillai links Shiva's grace not with the scholarly accomplishments celebrated by Navalar, but with a humility that opposes presumptions of superiority. ${ }^{94}$

In these initial pages of his response to Navalar, Pillai draws on a specific set of texts to advance his argument. He cites Shaiva bhakti works themselves rather than the scholastic works that Navalar draws on. This allows Pillai to emphasize the parallels between Ramalinga and the Shaiva saints, particularly the human imperfections to which all Shaiva saints admit. Moreover, by citing Tayumanavar, a Shaiva poet whose writings are not part of the Tirumurai nor on Navalar's list of arutpia, Pillai extends the category of arutpa to a relatively recent figure. He points out that Navalar does not consider even the Tirumantiram to be arutpa $\bar{a}$, even though it is part of the Tirumurai; has a form similar to that of Periya Purānam; and its author, Tirumular, is one of the Shaiva saints extolled in the Periya Purānam. He asks, "who is qualified to attack in this way, looking at texts written by wise people and saying that only some can bestow grace, and others cannot?" He contrasts Navalar, who in his arrogance decides which poems are arutpa and which are not, and poet-saints like Sambandar, who shows the way to god by expressing their doubts and suffering. ${ }^{95} \mathrm{He}$ characterizes Navalar's attempt to limit the category of arutpa as an act of hubris. Although Pillai does not explicitly mention Ramalinga in this passage, he certainly considers Ramalinga to be akin to the poet-saints, and so the underlying contrast he draws is between Ramalinga and Navalar, between the wise, humble poet-saint and the worldly, arrogant scholar.

Pillai argues that many works share the characteristics of arutpia, not just the five that Navalar lists. He cites a verse that he attributes to the female saint 
Auvaiyar: "Tirukkural, the four Vedas, the speech of the three Tamil saints [i.e., the Tèvāram], Tirukkovaiyar, Tiruvācakam, Tirumular's words [i.e., Tirumantiram], understand that all of these are the same." Pillai criticizes Navalar's attempts to disparage some saints and points out that Navalar teaches "high and low." He contrasts Navalar's attitude to a position of "great virtue" and humility, which entails seeing that all the poems of saints who have received Shiva's full grace are arutpia. Pillai continues, "Why, then, is Navalar now declaring that the work which has been published with the name 'Tiruvarutpā' is not deserving of the title of a new scripture, and moreover that the wisdom and experiences in that scripture are lies? Are such experiences [of Shiva] impossible for everyone in this present time? Or can one dare say that they are only impossible for Navalar?"96 Pillai asserts that new experiences of Shiva are possible, and he explains Navalar's rejection of this possibility as an indication of Navalar's own lack of Shiva's grace.

Pillai attests that Ramalinga has indeed received the nectar of bliss from Shiva. He affirms that Ramalinga has performed many miracles, demonstrating that he is dear to Shiva; that he received Shiva's grace; that Shiva took pains to come to Ramalinga and embraced him; and that he deserves the title "benevolent one with the splendor of grace." He also extolls the literary quality of Ramalinga's poems, citing the following verse as an example: "Wanting to see you, Vishnu and Brahma abandoned their dignity and assumed animal forms, but they couldn't fathom you, benevolent one. I am a cruel man, with a heart as coarse as a husk of grain. Without any principles, I'm not able to know you. Oh pure one who dances in the hall, in your grace, manifest yourself to me. Otherwise, it will be impossible for me." ${ }_{97}$ Pillai asserts that "when reading this verse aloud, it is clear that Tiruvarutpā has the same literary fineness that is exemplified in the Tèvāram and Tiruvācakam." Thus, Pillai argues, Ramalinga's work conveys not only the experience of Shiva's grace but also the literary qualities of the finest Tamil Shaiva bhakti works. He extols Ramalinga's statements that he is not worthy of Shiva's grace, seeing this humility as itself evidence of grace. Pillai cites Ramalinga's performance of miracles as further evidence of Shiva's grace, and asserts that Navalar, in denying Ramalinga's extraordinary abilities, also denies the power of grace. Pillai addresses Navalar's demand that Ramalinga perform miracles in public, pointing out that no one saw the saint Tirumular abandon his body, and that other Shaiva saints did not publicize their miracles. He notes that Chidambara Swami, head of the Madurai monastery, praised Ramalinga in a verse that exclaims the miracle of the water lamp, invoking monastic support for Ramalinga's abilities. He calls Navalar's denial of Ramalinga's miracles a "great sin," comparing Navalar to people of other religions who question the power of Shiva's grace..$^{8}$

Pillai was certainly aware of the irony of comparing Navalar to other critics of Shaivism. After all, much of Navalar's polemical writing was directed against missionary critics of Shaivism and Hinduism, and Navalar criticized Ramalinga precisely for not attacking other religious traditions. Pillai writes that Navalar, in 
his polemical lecture, warned that Christians would ridicule attempts to claim canonical status for Ramalinga's poems, which would bring all other Shaiva works into disrepute. ${ }^{99}$ If Pillai has accurately represented Navalar's position, it provides evidence that Navalar forged his new vision of Shaivism with an eye to the sensibilities of missionaries and other Westerners. Pillai responds that Christians and people of other religions are not Shaivas and so they can say what they want, and that Navalar should instead be concerned about what he is saying. Pillai's response indicates that Ramalinga and his followers had little desire to engage with Christians or to resist missionary evangelization. Pillai does not see Christians as a threat, and instead he viewed Navalar's attack as a more serious challenge to Ramalinga's teaching. He concludes by questioning Navalar's integrity, honesty, and closeness to Shiva. He reasons that because Tiruvarutpā facilitates experiences of grace, Navalar's polemic against it indicates that Navalar does not recognize Shiva's grace. He worries that Navalar is incurring great sin in opposing Ramalinga and "prays to Navalar's lotus feet" that Navalar joins the path of grace. ${ }^{100}$

Pillai's response adhered closely to the conception of Shaiva tradition that Ramalinga expressed in his poems. Contrary to Navalar's view of tradition, which paralleled emerging cosmopolitan redefinitions of Hinduism, Ramalinga and his followers asserted a Shaiva tradition that was inclusive and flexible. Pillai argued for a diffuse conception of Shaiva authority, one which did not depend on scholastic traditions of interpretation that were composed in the context of monastic institutions and established lineages of authority. He also promoted a radically different view of modernity, one receptive to the performance of miracles and the direct experience of Shiva. Pillai asserted these views by engaging with revered canonical literature, presenting a comparison of Ramalinga's poems and feats with those of the Shaiva saints. In other words, by ignoring the well-established traditions of Shaiva scholasticism that Navalar holds as the gatekeepers of authority, Pillai engaged in an interpretive enterprise, advancing his own reading of Shaiva tradition.

\section{CONCLUSION}

The debate between the Ramalinga and Navalar camps was most explicitly over the status of Ramalinga's verses and the authority wielded by Ramalinga. More broadly, it was about two contrasting visions for Shaivism. Navalar indicated this when he asked Ramalinga's followers, "what sort of Shaiva tradition do you follow?"101 In his defense of Ramalinga, Shanmugam Pillai similarly asks, "what sort of Siddhantam" does Navalar where "Siddhantam" functions as a synecdoche for Shaiva doctrine. ${ }^{102}$ Both camps, then, acknowledge that their debate was over the shape of Shaiva tradition, canon, and authority. Both stressed the continuities of their visions within Shaiva traditions. Navalar saw himself as carrying on the work of monastery-based Shaiva scholars, who in past centuries compiled, interpreted, 
and authorized the corpus of Shaiva literature. Ramalinga, on the other hand, bypassed this scholarly tradition by emphasizing links to the canonical poet-saints themselves. If Navalar was authorizing canon, Ramalinga was creating new canon, yet both situated their projects within Shaivism. They were right to highlight their links to past texts and traditions, and both were products of long-standing Shaiva traditions of education. However, they also innovated in important ways, and both of their projects were modern in the sense that I have been using the term. That is, both Ramalinga and Navalar were aware of the unique challenges of their present; both innovated in strategic ways that responded to those challenges; and both oriented their actions in anticipation of future trends. By looking at these two leaders together, it becomes clear that there was no single, monolithic, or perhaps even hegemonic, expression of modernity in Tamil Shaivism in their time.

The antipathy between the two camps derived in part from the very different ways that they conceived of tradition, history, and revelation. Navalar's sense of tradition reflected Protestant insistence that the miraculous was confined to a revered past. His denial that miracles or revelation could occur in the present posed a radical, temporal break between an enchanted past tradition and a rational present. Navalar and other cosmopolitan reformers insisted that this sacred past required translation in the present, which consisted of explanation in rational terms. For Navalar, scholarly traditions supported by established Shaiva institutions were required to perform this work of translation. He used publishing to advance this project, making available the teachings and messages of canonical works at the same time that he drew the boundaries of canon and its criteria for inclusion.

From the perspective of Ramalinga, however, there was no radical, temporal break with the past. Past tradition was not an object of authority to be interpreted from a radically different present. Rather, Ramalinga expressed a "lived" relationship with tradition, emphasizing the contemporaneity of himself and tradition. He described how the nāyanmār appeared to him, spoke to him, and inspired him. Rather than assuming a critical break with the past, Ramalinga claimed to be part of the assembly of Shaiva poet-saints. In promoting the most accessible aspects of Shaiva tradition, and in dismissing the importance of scholastic learning, he disputed Navalar's emphasis on the necessity of established, elite mediators. His poems describe his close, personal interactions with Shiva and suggest the accessibility of Shiva to all worshipers. He conceived of tradition as flexible, allowing new experiences of revelation and expression of canon.

Ramalinga's vision of a living tradition, a new revelation, and the immediate presence of Shiva was grounded in Shaiva literary and devotional traditions that were more than a thousand years old. His conception of the past, it seems to me, was more consistent with enduring Shaiva notions than was Navalar's formulation, which imposed a radical break with the past and thus with prior Shaiva tradition. Ironically, perhaps, it was Ramalinga's "traditional" notion of a flexible 
tradition that more easily accommodated innovation and change. In other words, Ramalinga's "traditional” orientation promoted creativity and innovation, while Navalar's "modern" formulation valued stasis. We might in this case consider reversing the usual dichotomy between static tradition and dynamic modernity.

The dispute between the two groups also reflects the very different positions of authority that they occupied. Navalar wrote from the dais of the powerful Tiruvavadudurai monastery, and he defended the hierarchies that characterized established Shaivism. He supported the ritual hegemony of brahmans, and he promoted the scholarly authority of high-caste vellalars. Ramalinga, on the other hand, stood outside those halls of established Shaiva institutional power, and he advanced a notion of tradition that challenged those established powers. He boasted of having no human preceptor, and he identified with no lineage of contemporary worldly authority, instead placing himself in the line of Shaiva saints. The success of Ramalinga and his followers in effectively spreading their message is best testified by his many followers during his lifetime and afterward, and also by Navalar's response. Navalar's polemic presents important details of Ramalinga's emerging reputation as a saint capable of miraculous feats, and of the ritual employment of Ramalinga's verses in temples. Navalar's criticisms and ridicule of Ramalinga belie the very real threat that Ramalinga posed to Navalar and his vision of Shaivism.

Ramalinga's innovations drew on prior Shaiva traditions, but his vision was not simply a survival from the past. He and his followers were not blind to the shifts in authority and knowledge taking place in South Asian society. As we have seen, their sense of a tradition that is alive and open to new revelations allowed for radical innovations to Shaiva tradition. They developed a new ideology of charity that extended Shaiva ritual transaction to the anonymous poor. They exploited a newly available technology, print, to advance a vision of Shaivism that they hoped would have appeal across class and caste divisions. They conceived of bhakti works as living texts, pointing to Ramalinga's experiences and writings as evidence of the continuity of Tamil Shaiva devotional traditions and of Shiva's grace in the world. As we will see in the next chapter, their vision of a flexible and open tradition enabled a new configuration of yoga powers and religious community. Their articulation of a new Shaivism, and the appeal of their vision to people of varied castes, classes, and traditions, suggests that while they drew on established Shaiva idioms and models, they were not traditionalists stubbornly clinging to the past. Instead, they deliberately formulated a vision that could respond to the challenges of their time.

There are important conclusions to draw from Ramalinga's success. First, while new assertions of the dominating authority of scripture and the location of all revelation in the distant past were gaining prominence, particularly in urban colonial settings, these were not the only important ways that tradition was being reformulated. There was much potential for Hindu leaders on the margins of power to advance ideas of tradition that were less tied to cosmopolitan notions, but which 
were nevertheless timely, persuasive, and inspirational. Second, these divergent visions often came into conflict. In the case of the arutpa-marutpa $\bar{a}$ conflict, no clear "winner" emerged. Navalar's scholarly legacy is well established, since he was a pioneer in the editing and publication of classical Tamil works. His vision of a systematized Shaivism certainly has its threads of continuity today, where, in temples like the Minakshi temple in Madurai, priests attend Agamic schools that seek to ensure that temple ritual is performed according to the Agamas. ${ }^{103}$ But his vision never gained prominence outside of elite, scholarly circles.

Ramalinga's legacy, on the other hand, is more wide ranging. He is respected in literary spheres for his verse writing. He was appropriated by Tamil nationalists in the twentieth century as an ideological forefather because of his critiques of caste. Tamils of many castes and classes continue to revere his verses and sing them in ritual contexts. Groups in India and abroad perpetuate his vision and carry on his work, especially his outreach to the poor. His formulation of tradition has proved to be the more popular one, and in many ways the more modern one. When we look for the origins of modern Hinduism, we need to look beyond cosmopolitan reformers. We also need to look at figures like Ramalinga. 